\title{
The Impacts of Power Infrastructure Development in the Socio-Economic Situations in Sub-Sahara Africa
}

\author{
Ngcobo Ntebo, Kasenge Mathe and Emmanuel Oikelomen Ayorinde* \\ Department of Civil Engineering Technology, University of Johannesburg, South Africa
}

\begin{abstract}
Infrastructural development is fundamental in nation's economic growth and development. Power infrastructure is imperative for nation building and helps create employment and improved the well-being of its citizens. This research paper identifies the impact of power infrastructure development on the economic growth in sub-Saharan Africa (SSA). The study adopted a quantitative research approach with data gathered from the respondents within power infrastructure development in the region. Information gathered were analysed using mean item score, standard deviation and factor analysis. The findings revealed the impact of power development on the economic benefit in SSA to be wealth creation, boost in citizens' income, health care improvement, improved educational systems were seen as the direct impact of infrastructure development on the economic situation in sub-Sahara Africa. Since the lack of infrastructural facilities of an economy can lead to various setbacks in the nation's economic development, it thereby requires adequate participations by stakeholders to deliver sustainable power infrastructure development in the society. The study power infrastructure development can contribute to regional and national growth, urbanization challenges, and improvement in the environmental through the provision of clean energy which foster social and economic inclusion.
\end{abstract}

\section{Introduction}

The expenditures in infrastructure development is the highest in emerging and developing countries, especially the ones with the highest growth, such as India and China in particular. These two nations, together with Brazil, South Africa, and Russia, make up the so-called BRICS, which in 2012 produced one-quarter of the world's gross domestic product (GDP) (1). Therefore, emerging nations require huge capital investment as a way of developing infrastructure for the purpose of economic growth and development.

Also, according to the Organization for Economic and Cooperation Development (OECD), the everincreasing size in globalization and urbanization by the year 2030 for telecommunication, water, transportation and power generation, transmission and distribution will amount to \$71 trillion. Therefore, the government cannot meet this target alone through annual budgets carried out by the awarding of direct contracts. There is a need for collaboration with the private sector to invest in infrastructure projects, to receive aids and bring about industrial growth and socio-economic development (2).

(3) Stated that urgent adequate unprecedented infrastructure is needed to tackle the increase in the population for a better standard of living through the provision of infrastructural" amenities such as power facilities. Sub-Saharan Africa (SSA) is in a profound crisis of low power output, which has constrained its economic growth rapidly and restrained development in

\footnotetext{
다responding author: engrkulz@gmail.com
}

the region. It is a known fact that the combined 48 countries of sub-Saharan Africa have about 80 gigawatts (GW), while a single country like Spain with a far smaller population generates more. Capital growth in the sub-Saharan region has been stagnant for the last three decades, with growth rates barely half of those in other developing countries. It has widened the gap between sub-Saharan Africa countries and the rest of the world, even compared to other nation groups in the same income bracket (4).

Therefore, it is fundamental for government and private investors to make huge investments in large, medium and small irrigation facilities. The large facilities will be responsible for the availability of water provision, irrigation and hydroelectric power (5). Investments in the energy sectors have resulted in improvements in the standard of living of citizens, thereby eradicating poverty and boosting the economic growth in the world (5).

Developed nations in the world have striven to remain above the subsistence economic growth through the secured access to electricity delivered to its citizens (6). Secured access to energy services has improved education, improved incomes for the citizens, and improved the healthcare sector, improved gender equality as well as several other socio-economic growths $(7 ; 8)$. The development of human resources and the economic growth of a country requires secure energy services (9). It is known that adequate provision of secured energy services in SSA will increase the socioeconomic growth of the region, and help in the 
actualization of the Millennium Development Goals (MDGs) (10). The study of (11) agrees with that of (12) that a secured power generation transmission and generation will boost industrialization and economic growth in SSA.

Effective power infrastructure development is a prerequisite for economic growth, improved competition, industrialization and earned recognition and induction into the world economy (13). The effective growth in the energy sector in India for about 20 years between 1972 and 1992 accounted for about half of the Indian industrialization growth (11).

\section{Methodology}

The method used in this study was quantitative research approach with the motive of achieving the aim of the study, which is to identify the impacts of power development on the socio-economic situations in SSA. Quantitative methods relate to positivism and factual data (14). The questionnaire was developed from a wide review of the literature and is not part of any existing survey instrument. Practicing power infrastructure professionals in the power sector in SSA were engaged in the collection of the primary data on the impact of power development on the economic benefit in SSA.

The Likert scale (strongly agree $=5$, agree $=4$, neutral $=3$, disagree $=4$, strongly disagree $=5$ ) Mean item score (MIS) was used to present the research findings from the Likert scale in a decreasing order.

Exploratory factor analysis (EFA) is one of the two types of factor analysis (FA), and is often deployed during the initial stage of research by researchers in order to collate information about the interrelationships within a set of variables (15). The EFA of the results were obtained to comfirm the validity and reliabilty of the impacts of power development on the socio-economic situations in SSA, with the highest likelihood with an eigen value of more than one, together with the varimax rotation EFA was used specifically for this study. SPSS software version 21.0 was used to conduct the EFA for this research. The descriptive results show the rankings of all the factors from the first to last according to the variables, with the table representing the individual variables' mean score as well as the standard deviation of the variables.

\subsection{Data analysis}

Two descriptive statistics were carried out, which are in the form of mean item score and factor analysis. The ranking of the variables was done with mean item score, likewise factor analysis was carried out to outline the variables measuring same underlying effects (16).

\subsection{Mean item score}

The mean ranking of the variables presented depicts the individual views reached on by the respondents. The result for the test is shown in the table below. The mean table represented below also include the standard deviation of the variables.

Table 1. Socio-economic impact of power development

\begin{tabular}{|c|c|c|c|}
\hline The Impact of Power Infrastructure Development & Mean & $\begin{array}{c}\text { Standard } \\
\text { Deviation }\end{array}$ & Rank \\
\hline Creation of wealth & 4.89 & 0.333 & 1 \\
\hline Creates jobs & 4.86 & 0.412 & 2 \\
\hline Reduces cost of productions & 4.77 & 0.472 & 3 \\
\hline Ensures a functioning economy & 4.77 & 0.421 & 4 \\
\hline Ensures a viable economic growth in the country & 4.76 & 0.430 & 5 \\
\hline Increases incomes & 4.75 & 0.452 & 6 \\
\hline Improves the standard of living of the people & 4.75 & 0.435 & 7 \\
\hline Ensures a socio-economic improvement & 4.73 & 0.460 & 8 \\
\hline Increase productions & 4.73 & 0.443 & 9 \\
\hline Increases the profitability of organizations & 4.68 & 0.484 & 10 \\
\hline Increased competition to boost economic growth & 4.66 & 0.536 & 11 \\
\hline Improves the confidence of investors in the economy & 4.65 & 0.509 & 12 \\
\hline It creates convenience, i.e. makes life easier for everyone & 4.63 & 0.500 & 13 \\
\hline Improves health care and education quality of the country & 4.45 & 0.584 & 14 \\
\hline It creates room for innovation & 4.44 & 0.542 & 15 \\
\hline $\begin{array}{l}\text { It creates connectivity between organizations and } \\
\text { international investors }\end{array}$ & 4.22 & 0.543 & 16 \\
\hline
\end{tabular}




\section{Results from factor analysis}

The EFA results of the impacts of power infrastructure development in economic situation are depicted in tables $1,2,3,4,5,6$ as well as fig 1 . With the sixteen variables outlined, two (2) of the variables were missing which are 'increases production' (EG11), and 'it creates convenience i.e. makes life easier for everyone' (EG13). The following were the fourteen variables identified with the potential of roles of power infrastructure development in economic growth.

Table 2. Definition of identified impacts of power infrastructure development on economic situation

\begin{tabular}{|c|c|c|}
\hline Variable & Variable name & Definition \\
\hline EG1 & Wealth creation & Increases the wealth of citizens. \\
\hline EG2 & Creates jobs & Room for more capital projects. \\
\hline EG3 & Reduces cost of production & Decreases the high cost of production. \\
\hline EG4 & Increases profitability of organization & Increases the profits establishments. \\
\hline EG5 & Increases income & Better standard of living. \\
\hline EG6 & Ensures a functioning economy & Viable economy. \\
\hline EG7 & $\begin{array}{l}\text { Increases competition to boost economic } \\
\text { growth }\end{array}$ & Healthy competition between competitors. \\
\hline EG8 & $\begin{array}{l}\text { Increases the confidence of investors in the } \\
\text { economy }\end{array}$ & The high rate of investments. \\
\hline EG9 & $\begin{array}{l}\text { Ensures a socio-economic growth of the } \\
\text { country }\end{array}$ & Boost the gross domestic product (GDP). \\
\hline EG10 & $\begin{array}{l}\text { Improves health care and education of the } \\
\text { country }\end{array}$ & Better health care and learning. \\
\hline EG12 & $\begin{array}{l}\text { Ensures a viable economic growth of the } \\
\text { country }\end{array}$ & Improved economy. \\
\hline EG14 & $\begin{array}{l}\text { Improves the standard of living of the } \\
\text { people }\end{array}$ & Improves citizens incomes. \\
\hline EG15 & Creates room for innovation & It ensures creativity and manpower production. \\
\hline EG16 & $\begin{array}{l}\text { Increases connectivity between } \\
\text { organizations and international investors }\end{array}$ & Smooth communication for transactions. \\
\hline
\end{tabular}

Factor analysis is vital in breaking down numbers of large variables and breaking them into more simple clusters for better interpretations (17). Table 3-6 and fig. 1 below shows (table 3) Kaizer-Meyer-Olkin (KMO), the measure of sampling adequacy attained a high score of 0.802 (Table 4) The Bartlett test of sphericity also was important, this suggest that the matrix of population is not an identical matrix. In addition, the Cronbach alpha that measures internal consistency is 0.802 , thus suggest that the reliability of the instrument used by the researcher in the research is quite good.

Table 3. KMO and Bartlett's test

\begin{tabular}{|l|l|c|}
\hline \multicolumn{2}{|l|}{$\begin{array}{l}\text { Kaiser-Meyer measure of sampling } \\
\text { adequacy }\end{array}$} & .802 \\
\hline $\begin{array}{l}\text { Bartlett's test of } \\
\text { sphericity }\end{array}$ & $\begin{array}{l}\text { Approx. } \\
\text { chi-square }\end{array}$ & 924.479 \\
\cline { 2 - 3 } & df & 91 \\
\cline { 2 - 3 } & Sig. & .000 \\
\hline
\end{tabular}

The data was regulated with principal component analysis (with varimax rotation). The Eigen values has a high value of more than 1 . As represented in table 5 and also see figure 1 , the factor loading extracted was eight 
components with the eigenvalue more than 1 and 0.5 (see fig. 1 scree plot). For the total variance (see table 6), as explained by each component extracted; component 1 (41.135\%), component 2 (13.893\%), component 3
$(9.082 \%)$. Therefore, the result from the principal component analysis (PCA) and the factors extracted amounted to $64.11 \%$ of the total cumulative variance.

Table 4. Correlation matrix of factor analysis

\begin{tabular}{|c|c|c|c|c|c|c|c|c|c|c|c|c|c|c|}
\hline $\begin{array}{l}\text { C. } \\
\text { matrix }\end{array}$ & EG1 & EG2 & EG3 & EG4 & EG5 & EG6 & EG7 & EG8 & EG9 & EG10 & EG12 & EG14 & EG15 & EG16 \\
\hline EG1 & 1.000 & .722 & .526 & .358 & .228 & .263 & .437 & .366 & .313 & .093 & .246 & .185 & .176 & -.081 \\
\hline EG2 & .722 & 1.000 & .537 & .496 & .338 & .338 & .398 & .414 & .401 & .147 & .318 & .224 & .285 & -.062 \\
\hline EG3 & .537 & .537 & 1.000 & .517 & .268 & .315 & .234 & .240 & .424 & .128 & .328 & .093 & .155 & .047 \\
\hline EG4 & .358 & .496 & .517 & 1.000 & .541 & .542 & .197 & .538 & .544 & .408 & .434 & .381 & .333 & .268 \\
\hline EG5 & .228 & .338 & .268 & .541 & 1.000 & .381 & .339 & .315 & .523 & .376 & .510 & .496 & .327 & .288 \\
\hline EG6 & .263 & .338 & .315 & .542 & .381 & 1.000 & .331 & .483 & .633 & .486 & .453 & .480 & .274 & .254 \\
\hline EG7 & .437 & .398 & .234 & .197 & .339 & .331 & 1.000 & .596 & .343 & .450 & .334 & .188 & .519 & .259 \\
\hline EG8 & .366 & .414 & .240 & .538 & .315 & .483 & .596 & 1.000 & .450 & .434 & .413 & .328 & .503 & .224 \\
\hline EG9 & .313 & .401 & .424 & .544 & .523 & .633 & .343 & .450 & 1.000 & .452 & .483 & .544 & .348 & .204 \\
\hline EG10 & .093 & .147 & .128 & .408 & .376 & .486 & .450 & .434 & .452 & 1.000 & .411 & .301 & .521 & .597 \\
\hline EG12 & .246 & .318 & .328 & .434 & .510 & .453 & .334 & .413 & .483 & .411 & 1.000 & .449 & .264 & .262 \\
\hline EG14 & .185 & .224 & .093 & .381 & .496 & .480 & .188 & .328 & .544 & .301 & .449 & 1.000 & .405 & .331 \\
\hline EG15 & .176 & .285 & .155 & .333 & .327 & .274 & .519 & .503 & .348 & .521 & .264 & .405 & 1.000 & .473 \\
\hline EG16 & -.081 & -.062 & .047 & .268 & .288 & .254 & .256 & .224 & .204 & .597 & .262 & .331 & .473 & 1.000 \\
\hline
\end{tabular}

Table 5. Rotated factor matrix

\begin{tabular}{|c|c|c|c|}
\hline \multirow{2}{*}{ Factor Matrix } & \multicolumn{3}{|c|}{ Factors } \\
\hline & 1 & 2 & 3 \\
\hline Ensures socio-economic improvement & .747 & & \\
\hline Improves the standard of living of the people & .724 & & \\
\hline Increases income & .699 & & \\
\hline Ensures a functioning economy & .692 & & \\
\hline Increases profitability of organizations & .684 & & \\
\hline Ensures a viable economic growth of the country & .657 & & \\
\hline Creates room for innovation & & .784 & \\
\hline Increased competition to boost economic growth & & .749 & \\
\hline Improves health care and education of the country & & .698 & \\
\hline $\begin{array}{l}\text { Increases connectivity between organizations and international } \\
\text { investors }\end{array}$ & & .632 & \\
\hline Improves the confidence of investors on the economy & & .600 & \\
\hline Wealth creation & & & .857 \\
\hline Creates job & & & .833 \\
\hline Reduces cost of production & & & .673 \\
\hline \multicolumn{4}{|l|}{$\begin{array}{l}\text { Extraction method: Principal component analysis. } \\
\text { Rotation method: Varimax with Kaiser Normalization. }{ }^{\text {a }} \text { a. Rotation } \\
\text { converged in } 7 \text { iterations }\end{array}$} \\
\hline
\end{tabular}

Table 6. Total variance explained

\begin{tabular}{|c|c|c|r|r|r|r|r|r|r|}
\hline \multirow{2}{*}{ Factors } & \multicolumn{4}{|c|}{ Initial eigenvalues } & \multicolumn{3}{|c|}{ Extraction sums of squared loadings } & \multicolumn{3}{c|}{ Rotated sums of squared loadings } \\
\cline { 2 - 10 } & Total & $\begin{array}{c}\text { \% of } \\
\text { Variance }\end{array}$ & Cumulative \% & Total & $\begin{array}{c}\text { \% of } \\
\text { Variance }\end{array}$ & Cumulative \% & Total & $\begin{array}{c}\text { \% of } \\
\text { Variance }\end{array}$ & Cumulative \% \\
\hline 1 & $\mathbf{5 . 7 5 9}$ & 41.135 & 41.135 & 5.759 & 41.135 & 41.135 & 3.580 & 25.575 & 25.575 \\
\hline 2 & $\mathbf{1 . 9 4 5}$ & 13.893 & 55.028 & 1.945 & 13.893 & 55.028 & 2.698 & 19.273 & 44.848 \\
\hline 3 & $\mathbf{1 . 2 7 1}$ & 9.082 & 64.110 & 1.271 & 9.028 & 64.110 & 2.697 & 19.262 & 64.110 \\
\hline 4 & .822 & 5.873 & 69.983 & & & & & & \\
\hline
\end{tabular}




\begin{tabular}{|c|c|c|c|l|l|l|l|l|l|}
\hline 5 & .741 & 5.296 & 75.279 & & & & & & \\
\hline 6 & .660 & 4.714 & 79.993 & & & & & & \\
\hline 7 & .571 & 4.077 & 84.070 & & & & & & \\
\hline 8 & .499 & 3.561 & 87.631 & & & & & & \\
\hline 9 & .458 & 3.274 & 90.905 & & & & & & \\
\hline 10 & .374 & 2.669 & 93.574 & & & & & & \\
\hline 11 & .305 & 2.182 & 95.756 & & & & & & \\
\hline 12 & .245 & 1.748 & 97.504 & & & & & & \\
\hline 13 & .190 & 1.360 & 98.864 & & & & & & \\
\hline 14 & .159 & 1.136 & 100.000 & & & & & & \\
\hline
\end{tabular}

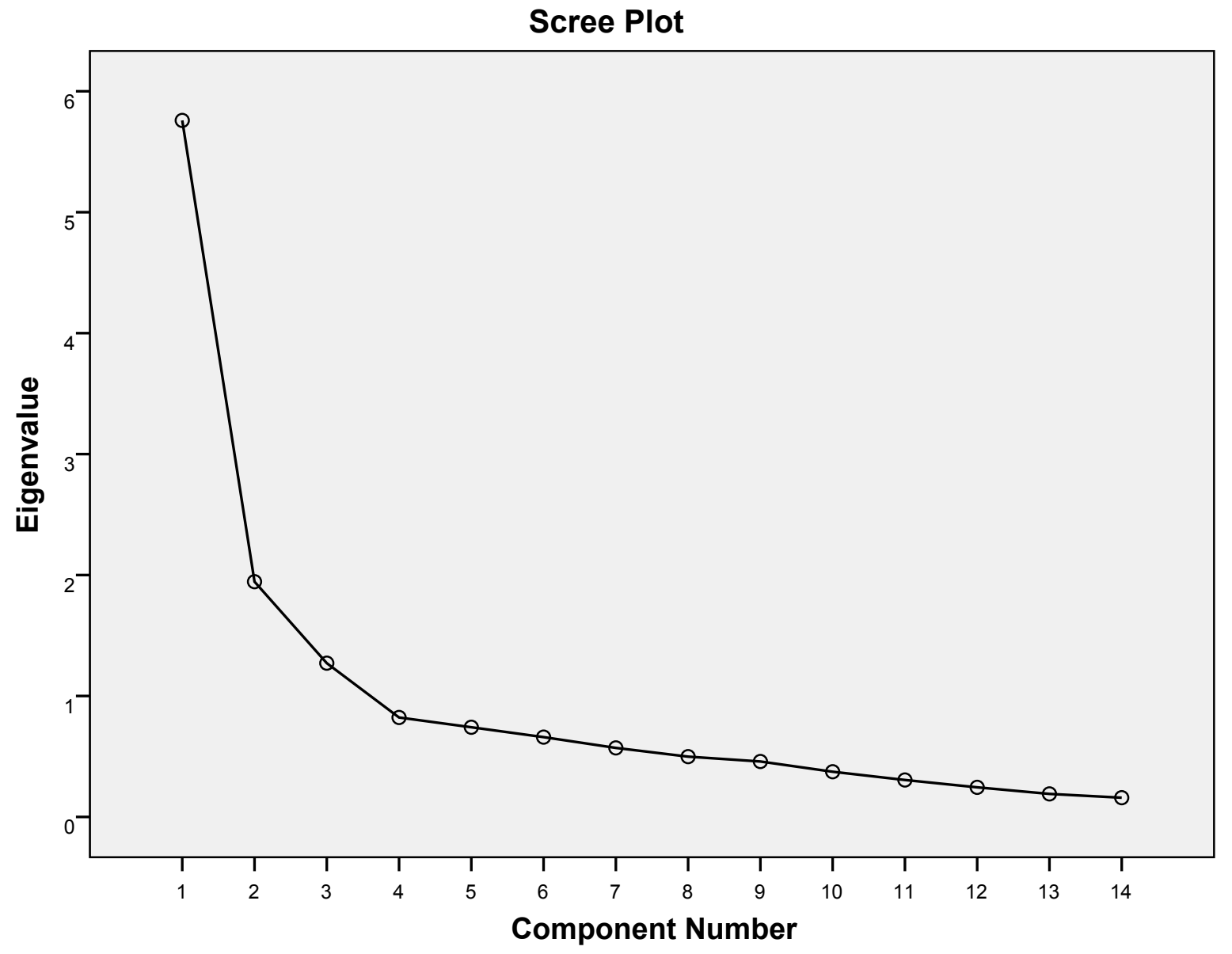

Fig. 1. Scree Plot for Factor Analysis 
The principal axis factoring used showed that three (3) were present with eigen value greater than 1 as represented in the table 6 . above. Due to the careful observation of the inherent connections among each of the variables under each factor, the following assessments were made. Factor 1 was described as economic and social development; factor 2 was described as environmental and welfare development and factor 3 was termed income and industrial improvement. The term used in describing these factors was gotten as a result of closely observing the variable within each of the factors. The three factors extracted and its constituents indicators are explained below, together with a comprehensive descripytion on how it was described the three factor sections.

\section{Discussion of results}

\section{Factor 1: economic and social development}

As shown in table 5 above, the three (3) was extracted as the impact of power infrastructure development on economic growth. For factor 1 were 'ensures socioeconomic improvement $(74.7 \%)$, improves the standard of living of the people $(72.4 \%)$, increases incomes (69.9\%), ensures a functioning economy (69.2\%), increases profitability of organisations $(68.4 \%)$, ensures a viable economic growth in the country $(65.7 \%)$. The number in the parenthesis showcase the individual factor loadings, also the definition of these variables are explained in table 6 this cluster acounted for $41.135 \%$ of the variance.

\section{Factor 2: environmental and welfare development}

As shown in table 6 above, three (3) was extracted as the impact of power infrastructure development on economic growth. For factor 2 were it creates room for innovation $(78.4 \%)$, increased competiton to boost economic growth $(74.9 \%)$, improves health care an education of the country $(69.8 \%)$, it increases connectivity between organisations and international investors $(63.2 \%)$ and improves the confidence of investors on the economy $(60.0 \%)$. The number in the parenthesis showcase the individual loadings, also the definition of these variables are explained in table 6 above. This cluster accounted for $13.893 \%$ of the variance.

\section{Factor 3: income and industrial improvement}

As shown in table 5 above, three (3) was extracted as the impact of power infrastructure development on economic growth. For factor 3 were 'wealth creation' $(85.7 \%)$, 'creates jobs' $(83.3 \%)$, and 'reduces cost of productions' $(67.3 \%)$. The numbers in the parentheses show the individual loadings. The definitions of these variables are explained in table 6 above. This cluster accounted for 9.028 per cent of the variance.

\section{Implication of study}

From the findings, the theoretical reviews conform to the empirical findings. It can be concluded from the study that wealth creation is the most important impact power infrastructure development has in the economic growth in SSA. It creates jobs, reduces cost of production, ensures a functioning economy, increases productions, and increases income. To be able to achieve these benefits the development of power infrastructure development in SSA is essential. Preference must be given to the power sector to be able to achieve these benefits for an industrialised and functioning economic in SSA. Finally, the role power infrastructure development has in the economic growth in SSA and other nations cannot be over-emphasized. SSA, therefore, requires urgent implementation of this study to achieve the required growth.

\section{Conclusion}

Results from the literature review established that the following are the impact of power infrastructure development in economic growth of SSA. It creates employment, alleviates poverty, provides better health care, and improves the country's gross domestic product (GDP). The literature has further shown that other benefits power infrastructure development has on the economic growth are an increase in the income of the citizens, and more investment in the economy by investors.

Results from the findings of the secondary data i.e. the questionnaire survey indicate that there are ten main impact of power infrastructure development on the economic growth in SSA are: wealth creation, job creation, reduction in the cost of productions, a functioning economy, viable economic growth of the country, increased income, improvement in the standard of living of the people, a socio-economic improvement, improved health care and education of the country and increased competition to boost economic growth. It can be conclusively be said that the research objectives for this study has been answered.

\section{References}

1. Wilson, D. \& Purushothaman, R. (2003). Dreaming with BRICs: The path to 2050. Global Economics Paper, (99):1.

2. Emenike, D. (2016). A qualitative case study of Nigeria electric power outage and its economic consequence.

3. Estache, A. (2008). Infrastructure and development: A survey of recent and upcoming issues. Rethinking infrastructure for development, 247.

4. Youm, I., Sarr, J., Sall, M., Ndiaye, A. \& Kane, M. (2005). Analysis of wind data and wind energy potential along the northern coast of Senegal. Review.energy.renewable, 8(2005):95-108. 
5. Tortajada, C. (2016). Policy dimensions of development and financing of water infrastructure: The cases of china and India. Environmental Science \& Policy, 64177-187.

6. World Bank. (2000a). Fuel for thought. An environmental strategy for the energy sector.

7. International energy agency (IEA). (2003). the power to choose: Demand response in liberalized electricity markets.

8. Cabraal, R.A., Barnes, D.F. \& Agarwal, S.G. (2005). Productive uses of energy for rural development. Annual Review of Environment and Resources, pp.30117-144.

9. Modi, V., McDade, S., Lallement, D. \& Saghir, J. (2005). Energy services for the millennium development goals. Energy services for the millennium development goals.

10. Tunde, A.O., 2005, July. Small hydro schemestaking Nigeria's energy generation to the next level. In Power Engineering Society Inaugural Conference and Exposition in Africa, 2005 IEEE (pp. 112-119). IEEE.

11. Hulten, C.R., Bennathan, E. \& Srinivasan, S. (2006). Infrastructure, externalities, and economic development: A study of the Indian manufacturing industry. The World Bank Economic Review, 20(2):291-308.
12. Yadoo, A. \& Cruickshank, H. (2012). The role for low carbon electrification technologies in poverty reduction and climate change strategies: A focus on renewable energy mini-grids with case studies in Nepal, Peru and Kenya. Energy Policy, 42591-602.

13. Oshikoya, T.W. (2008). Nigeria in the global economy. Business Economics, 43(1):31-43.

14. Burns, N. \& Grove, S. K. (2005). The practice of nursing research conduct critique and utilization (5th edition). Pennsylvania: Elsevier.

15. Pallant, J. (2011). Multivariate analysis of variance. SPSS survival manual. Allen \& Unwin. Pallant, J. (2010). SPSS survival manual: $A$ step-by-step guide to data analysis using SPSS. Maidenhead. England: McGraw-Hill Education.

16. Ledwaba, M.J. (2012). Informal settlements and organisations in post-apartheid South Africa: The case of Bethlehem, Tshwane (Mini dissertation). Available online at: http://hdl.handle.net/10210/532.[Accessed 27 February 2017].

17. Ahadzie D, Proverbs D, Olomolaiye P. Critical success criteria for mass house building projects in developing countries. International Journal of Project Management. Pp-26(6):675-87, Aug 31, 2008. 